\title{
Anti-TNF-a Activity of Portulaca oleracea in Vascular Endothelial Cells
}

\author{
An Sook Lee ${ }^{1, \dagger}$, Jin Sook Kim ${ }^{2, \dagger}$, Yun Jung Lee ${ }^{1,3}$, Dae Gill Kang ${ }^{1,3 *}$ and Ho Sub Lee ${ }^{1,3, *}$ \\ 1 College of Oriental Medicine and Professional Graduate School of Oriental Medicine, Wonkwang \\ University, Shinyong-dong, Iksan, Jeonbuk, 570-749, Korea; \\ E-Mails: mama0099@nate.com (A.S.L.); shrons@wku.ac.kr (Y.J.L.) \\ 2 Korea Institute of Oriental Medicine, Jeonmin-dong, Yusung-gu, Daejeon, 305-811, \\ Republic of Korea; E-Mail: jskim@kiom.re.kr \\ 3 Hanbang Body-fluid Research Center, Wonkwang University, Shinyong-dong, Iksan, Jeonbuk, \\ 570-749, Korea
}

$\dagger$ These authors contributed equally to this work.

* Authors to whom correspondence should be addressed; E-Mails: dgkang@wku.ac.kr (D.G.K.); host@wku.ac.kr (H.S.L.); Tel.: +82-63-850-6933 (D.G.K.); +82-63-850-6841 (H.S.L.); +82-63-850-7260 (D.G.K.); Fax: +82-63-850-7260 (H.S.L.).

Received: 20 February 2012; in revised form: 20 April 2012 / Accepted: 2 May 2012 / Published: 10 May 2012

\begin{abstract}
Vascular inflammation plays a key role in the pathogenesis and progression of atherosclerosis, a main complication of diabetes. The present study investigated whether an aqueous extract of Portulaca oleracea (AP) prevents the TNF- $\alpha$-induced vascular inflammatory process in the human umbilical vein endothelial cell (HUVEC). The stimulation of TNF- $\alpha$ induced overexpression of adhesion molecules affects vascular cell adhesion molecule (VCAM)-1, intercellular adhesion molecule (ICAM)-1 and E-selectin for example. However, AP significantly suppressed TNF- $\alpha$-induced over-expression of these adhesion molecules in a dose-dependent manner. In addition, pretreatment with AP dose-dependently reduced an increase of the adhesion of HL-60 cells to TNF- $\alpha$-induced HUVEC. Furthermore, we observed that stimulation of TNF- $\alpha$ significantly increased intracellular reactive oxygen species (ROS) production. However, pretreatment with AP markedly blocked TNF- $\alpha$-induced ROS production in a dose-dependent manner. The western blot and immunofluorescence analysis showed that AP inhibited the translocation of p65 NF- $\kappa \mathrm{B}$ to the nucleus. In addition, AP suppressed the TNF- $\alpha$-induced degradation
\end{abstract}


of I $\kappa \mathrm{B}-\alpha$ and attenuated the TNF- $\alpha$-induced NF- $\kappa \mathrm{B}$ binding. AP also effectively reduced TNF- $\alpha$-induced mRNA expressions of monocyte chemoattractant protein (MCP)-1 and interleukin (IL)-8 in a dose-dependent manner. Taken together, AP prevents the vascular inflammatory process through the inhibition of intracellular ROS production and $\mathrm{NF}-\kappa \mathrm{B}$ activation as well as the reduction of adhesion molecule expression in TNF- $\alpha$-induced HUVEC. These results suggested that AP might have a potential therapeutic effect by inhibiting the vascular inflammation process in vascular diseases such as atherosclerosis.

Keywords: Portulaca oleracea; inflammation; NF- $\kappa \mathrm{B}$; reactive oxygen species (ROS); atherosclerosis

\section{Introduction}

Recent investigations of atherosclerosis have focused on vascular inflammation, providing novel insight into mechanisms of disease. Much evidence has demonstrated that inflammatory events contribute at each stage in the development of clinically significant atherosclerosis [1,2]. The recruitment of circulating monocytes/leukocytes to inflamed sites in the arterial wall is one of the earliest detectable events in atherogenesis. Endothelial cells recruit leukocytes by selectively expressing major adhesion molecules on the surface, for example, vascular cell adhesion molecules (VCAM-1), intercellular adhesion molecules (ICAM-1), and endothelial cell selectin (E-selectin) [3]. The pro-inflammatory cytokine, tumor necrosis factor (TNF)- $\alpha$, is a prototype "activation agonist" that modulates leukocyte adhesion and transmigration in vascular inflammatory diseases including atherosclerosis [4]. Previous studies have indicated that cytokines such as TNF- $\alpha$ change the shape and motility of endothelial cells, which could contribute to vascular leakage at the site of inflammation and that such cytokines stimulate an increase in the expression of cell adhesion molecules $[5,6]$. An increased expression of adhesion molecules by endothelial cells in human atherosclerotic lesions may lead to further recruitment of leukocytes to atherosclerotic sites.

TNF- $\alpha$ also activates signaling cascades that regulate the activation and translocation of redox-sensitive transcription factor $\mathrm{NF}-\kappa \mathrm{B}$, an obligatory mediator of the inflammatory response that causes transcriptional activation of genes encoding adhesion molecules [7]. Previous studies have shown that NF- $\mathrm{BB}$ activation is required for the up-regulation of adhesion molecules such as ICAM-1 and VCAM-1, which are responsible for monocyte adhesion and increased vascular inflammation $[8,9]$.

Increased oxidative stress in vascular cells is implicated in the pathogenesis of atherosclerosis. Reactive oxygen species (ROS) are important mediators in cellular injury, specifically, as a factor in endothelial cell damage. A potent factor in causing intracellular ROS formation in endothelial cells is TNF- $\alpha$, a pleiotropic inflammatory cytokine [10]. In addition, ROS may serve as a common intracellular messenger for various redox-sensitive transcription pathways that induce adhesion molecule expression in vascular endothelial cells [2,11]. Recent studies showed that substances with antioxidant activity could scavenge intracellular ROS and inhibit endothelial adhesiveness to monocytes by reducing the expression of various adhesion molecules [12,13]. 
Portulaca oleracea L. (Portulacaceae) is an edible plant and has been used as a folk medicine in many countries, acting as a diuretic, febrifuge, antiseptic, antispasmodic and vermifuge [14,15]. It has been shown to display pharmacological roles, including antibacterial [16], analgesic [17], skeletal muscle-relaxant [18] and wound-healing [19] activities. Many studies have also shown that the major bioactive components of Portulaca oleracea are flavonoids, coumarins, monoterpene glycoside and alkaloids [20,21]. Some research results indicated that Portulaca oleracea could also be used to reduce the incidence of cardiovascular diseases [22]. However, there are no reports on the efficacy of an aqueous extract of Portulaca oleracea (AP) on either the expression of the cell adhesion molecules or the adhesion monocytes to endothelial cells through the NF- $\mathrm{BB}$ signaling pathway. Therefore we investigated the anti-vascular inflammatory effect and molecular mechanism of AP in the TNF- $\alpha$-induced vascular inflammation process in primary cultured human umbilical vein endothelial cells (HUVEC).

\section{Results and Discussion}

The major finding of this study indicated that pretreatment with AP significantly suppressed the TNF- $\alpha$-induced intracellular ROS production and up-regulation of adhesion molecules in HUVECs by inhibiting the NF- $\kappa \mathrm{B}$ signaling pathway. The cytotoxicity was examined using an MTT assay, performed at $1-200 \mu \mathrm{g} / \mathrm{mL}$ concentration of AP. When incubated with AP $(1-200 \mu \mathrm{g} / \mathrm{mL})$ for $24 \mathrm{~h}$, cell viability did not show significant difference at each concentration; cytotoxicity observed at $200 \mu \mathrm{g} / \mathrm{mL}$ AP (Figure 1a). Therefore $100 \mu \mathrm{g} / \mathrm{mL}$ AP concentration was used as the maximum dose. Increased expression of cell adhesion molecules is an important aspect of inflammatory changes associated with atherosclerosis and contributes to the activation and recruitment of lymphocyte from adventitial vessels and the arterial lumen to the vessel wall [2]. Various agonists including cytokines such as TNF- $\alpha$ and chemokines induce endothelial cell activation. TNF- $\alpha$ stimulation of endothelial cells activates the cell surface expression of adhesion molecules such as ICAM-1, VCAM-1 and E-selectin [6,23]. The effects of AP on the VCAM-1, ICAM-1 and E-selectin expressions in TNF- $\alpha$-induced HUVEC were determined by ELISA. This data indicated that ICAM-1, VCAM-1, and E-selectin were expressed at low levels on unstimulated endothelial cells. However, treatment with cells to TNF- $\alpha(10 \mathrm{ng} / \mathrm{mL})$ for $6 \mathrm{~h}$ led to a marked increase of the surface expression of these cell adhesion molecules. Pretreatment with AP significantly inhibited the TNF- $\alpha$-induced cell surface expressions of VCAM-1 and ICAM-1 in a dose-dependent manner. However, E-selectin expression did not show significant difference (Figure 1b). The inhibitory effect of AP on the expression of the cell adhesion molecules was further confirmed by western blot analysis. As shown in Figure 2, the unstimulated HUVEC expressed low levels of ICAM-1 and VCAM-1 and E-selectin. Upon stimulation with TNF- $\alpha$, a substantial increase in the expression of all these three molecules was observed. Pretreatment with AP significantly inhibited the TNF- $\alpha$-induced expression of ICAM-1, VCAM-1 and E-selectin in a dose-dependent manner (Figure 2a,b). Thus, AP inhibited the TNF- $\alpha$-induced expression of cell adhesion molecules as measured using ELISA and confirmed by western blot analysis. Furthermore, the adhesion of leukocytes or monocytes to the vascular endothelium is an important step in the reaction to inflammation and development of atherosclerotic lesions. During early stages of atherosclerosis, circulating monocytes adhere to endothelial cells that line the vessel wall and 
transmigrate through the endothelium into the intimal extracellular matrix [24]. The recent study demonstrated that a small number of monocytes adhered to unstimulated HUVECs [25], whereas there was a marked increase in monocyte adherence to HUVECs that had been exposed to TNF- $\alpha$ [26]. To explore the effect of AP on endothelial cell-leukocyte interaction, we examined the adhesion of HL-60 cells to TNF- $\alpha$-activated HUVEC under static conditions. HUVEC were pretreated with different concentrations of AP $(10-100 \mu \mathrm{g} / \mathrm{mL})$ and the intensity of cell adhesion was evaluated by the quantification of BCECF-AM staining method. Corresponding with results from ELISA, the adhesion of HL-60 cells to TNF- $\alpha$-stimulated HUVECs was increased about 4.5-fold compared with the untreated cells, and this adhesion was markedly decreased by treatment with AP in a dose-dependent manner (Figure 3). Therefore, we found that treatment with AP significantly reduced monocyte adhesion to TNF- $\alpha$-induced HUVEC, which is due to the inhibition of adhesion molecules expression. These results suggested that AP could suppress the early pathogenesis of atherosclerosis by regulating the vascular inflammatory process.

Figure 1. Effects of an aqueous extract of Portulaca oleracea (AP) on cytotoxicity and endothelial cell surface expressions of vascular cell adhesion molecules (VCAM-1), intercellular adhesion molecules (ICAM-1), and endothelial cell selectin (E-selectin). (a) Confluent endothelial cell monolayers were incubated with various concentrations of AP for $24 \mathrm{~h}$. Cell viability was determined by MTT assay; (b) The endothelial cells were pretreated with AP and then stimulated with pro-inflammatory cytokine, tumor necrosis factor (TNF)- $\alpha(10 \mathrm{ng} / \mathrm{mL})$ for $6 \mathrm{~h}$. Cell surface expressions of ICAM-1, VCAM-1, and E-selectin were analyzed by cell ELISA, as described in the Materials and Methods. Values are expressed as mean \pm S.E. of three individual experiments. ${ }^{*} p<0.05, * * p<0.01$ vs. control, ${ }^{\#} p<0.01$ vs. TNF- $\alpha$ alone.

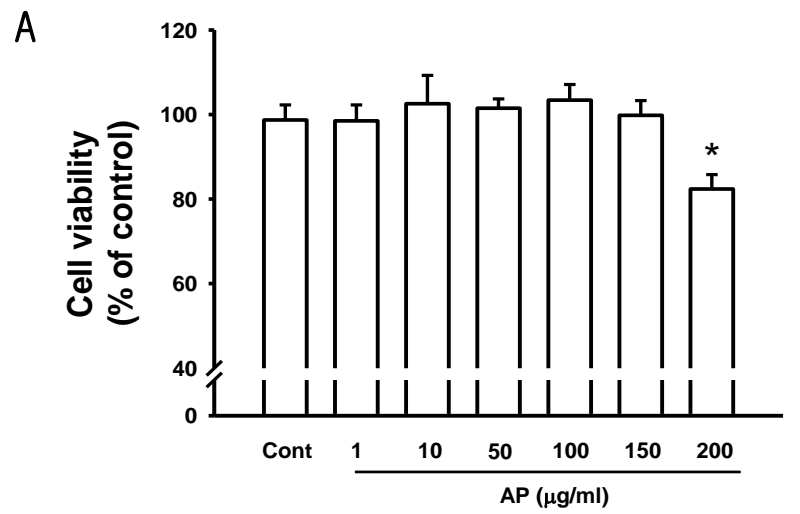

B

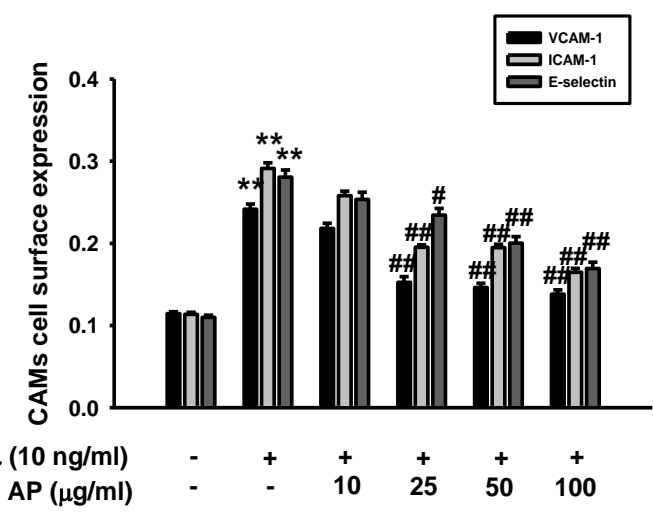


Figure 2. Effect of AP on TNF- $\alpha$-induced increases in protein expression of VCAM-1, ICAM-1, and E-selectin. (a) Primary cultured human umbilical vein endothelial cells (HUVECs) were pretreated with AP and then stimulated with TNF- $\alpha$ for $6 \mathrm{~h}$. After treatment, protein was extracted from the cells. VCAM-1, ICAM-1 and E-selectin protein levels were determined by western blot analysis; (b) Quantitative data are expressed as VCAM-1 (black), ICAM-1 (gray), and E-selectin (dark gray) normalized to $\beta$-actin, and the results are expressed as the fold of the control. Each electrophoretogram is representative of the results from five independent experiments. $* p<0.05,{ }^{*} p<0.01 v s$. control, ${ }^{\#} p<0.05,{ }^{\# \#} p<0.01$ vs. TNF- $\alpha$ alone.

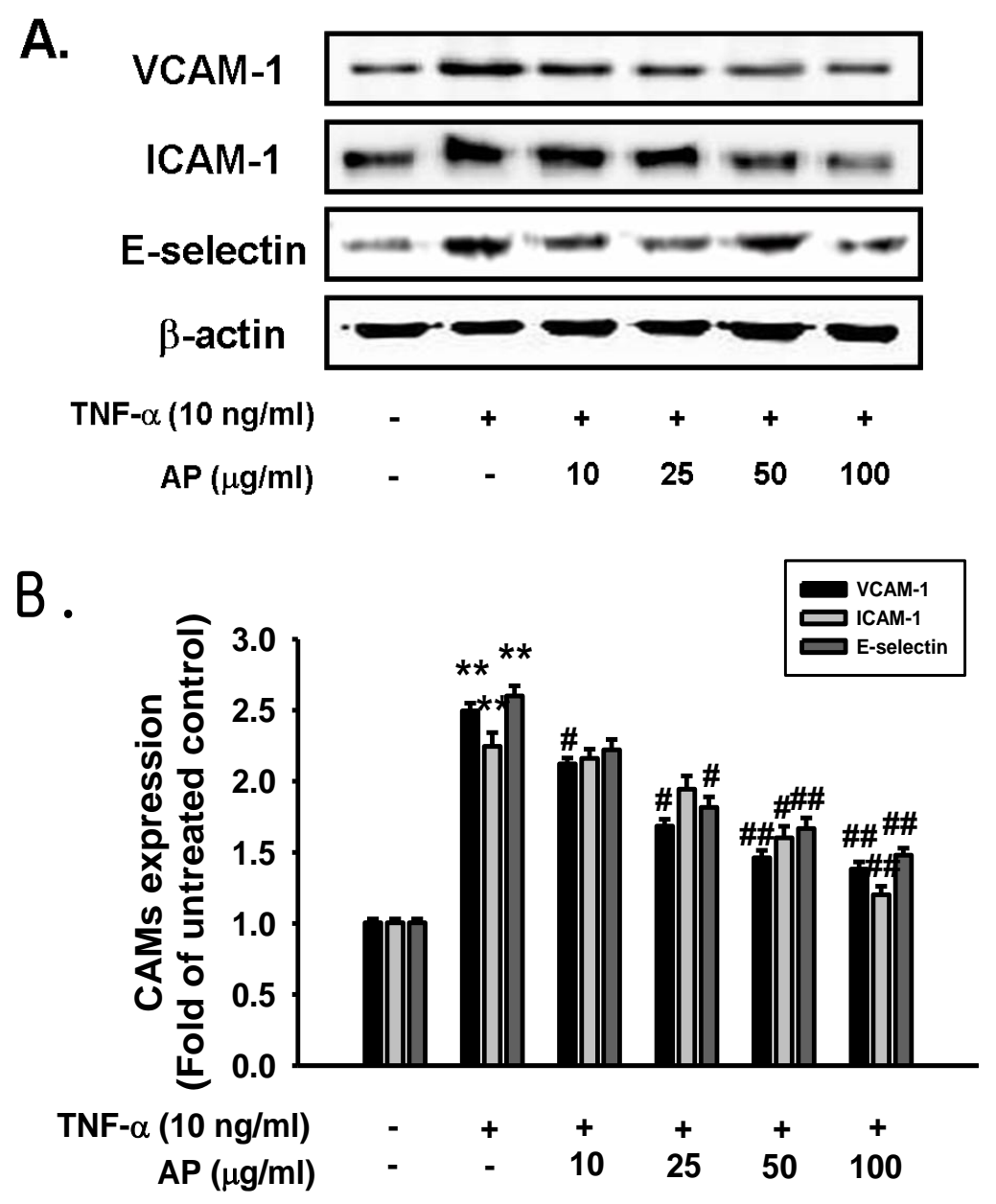


Figure 3. Effect of AP on TNF- $\alpha$-induced adhesion of HL-60 cells to HUVEC. Adhesion of fluorescence-labeled HL-60 cells to HUVEC was determined as described in Materials and Methods. (a) Control; (b) TNF- $\alpha$ (10 ng/mL); (c) co-treated with TNF- $\alpha$ and AP $(10 \mu \mathrm{g} / \mathrm{mL})$; (d) co-treated with TNF- $\alpha$ and AP $(25 \mu \mathrm{g} / \mathrm{mL})$; (e) co-treated with TNF- $\alpha$ and AP $(50 \mu \mathrm{g} / \mathrm{mL})$; (f) co-treated with TNF- $\alpha$ and AP $(100 \mu \mathrm{g} / \mathrm{mL})$. The amounts of adherent HL-60 cells were monitored by fluorescence microscopy. Low panel represents ratio of fluorescence intensity. Values are expressed as mean \pm S.E. of five independent experiments with triplicate dishes. ${ }^{* *} p<0.01$ vs. control, ${ }^{\#} p<0.05$, ${ }^{\#} p<0.01 v s$. TNF- $\alpha$ alone.
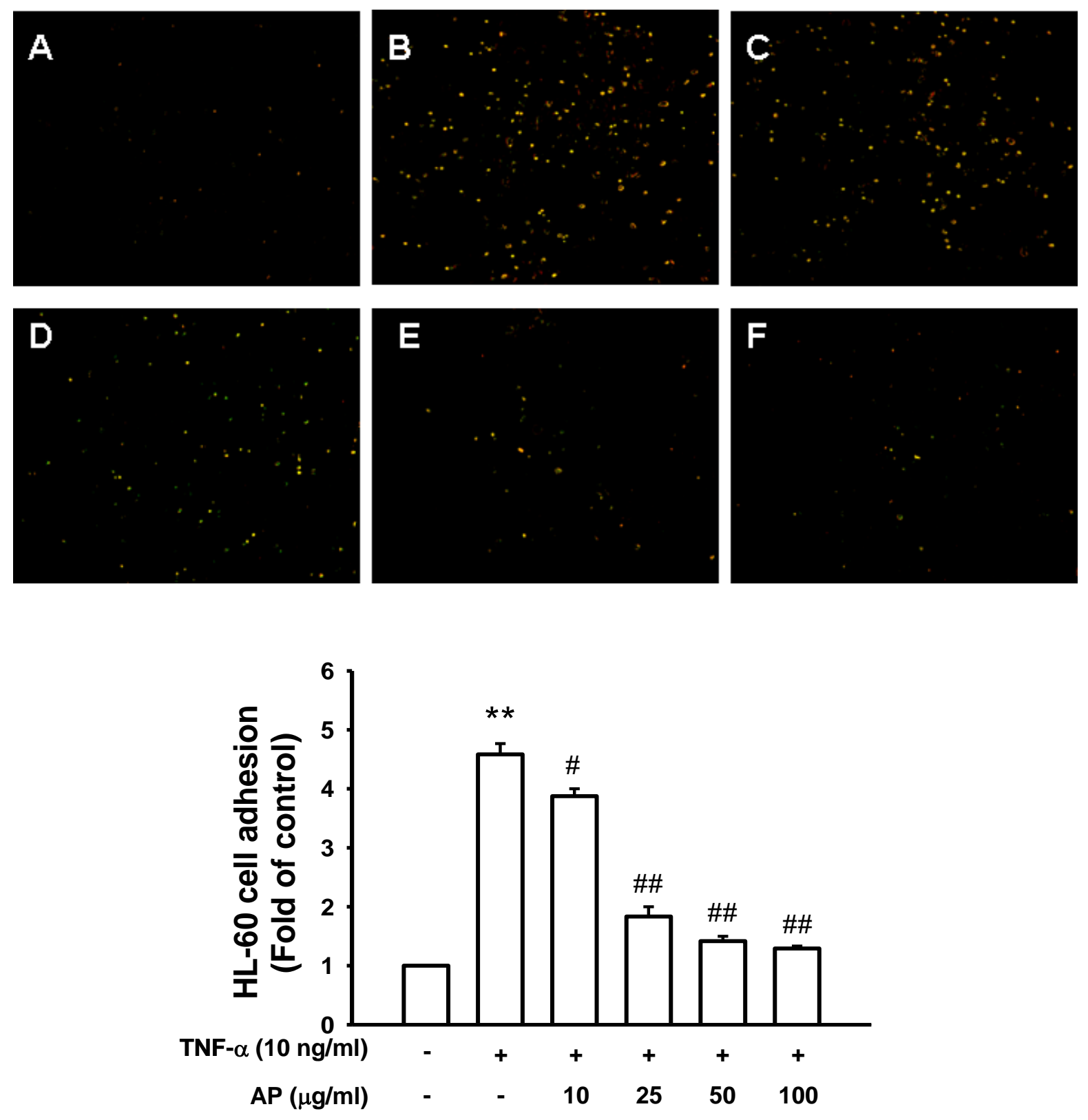

Induction of chemotactic cytokines such as IL-8 and MCP-1 is thought to play a key role in monocyte recruitment and adhesion to endothelial cells in atherosclerosis [27]. Previous studies have shown that chemokines and adhesion molecules are involved in causing atherosclerosis by promoting directed migration of inflammatory cells. Interleukin-8 (IL-8) is a $\mathrm{C}-\mathrm{X}-\mathrm{C}$ chemokine and acts as a 
chemoattractant of neutrophils, whereas monocyte chemoattractant protein-1 (MCP-1) is a $\mathrm{C}-\mathrm{C}$ chemokine and functions mainly as a chemoattractant of monocytes/macrophages [28]. Both factors are secreted from endothelial cells and have been implicated in the processes leading to atherosclerosis. To understand the mechanisms responsible for inhibition of MCP-1 and IL-8 expression by AP, we examined whether AP blocks the induction of their transcript levels. We performed a RT-PCR analysis on isolated RNA in HUVEC. This data indicated that the unstimulated endothelial cells had low levels of MCP-1 and IL-8 mRNA expression. Stimulation with TNF- $\alpha$ induced a marked increase in MCP-1 and IL-8 mRNA levels, while pretreatment with AP led to a significant reduction in their transcript levels (Figure 4). These results indicated that AP inhibited the transcription of MCP-1 and IL-8 genes under cytokine stimulation. Therefore, AP may be effective in suppression of the vascular inflammatory process associated with the development of atherosclerosis.

Figure 4. Effect of AP on TNF- $\alpha$-induced increase of monocyte chemoattractant protein-1 (MCP-1) (a) and Interleukin-8 (IL-8) (b) mRNA expression. HUVEC were pretreated with AP and then stimulated with TNF- $\alpha$. MCP-1 and IL- 8 mRNA expression was determined by RT-PCR. Values are expressed as a fold of basal value and are the mean \pm S.E. of five independent experiments. $* * p<0.01 v s$. control, ${ }^{\#} p<0.01 v s$. TNF- $\alpha$ alone.
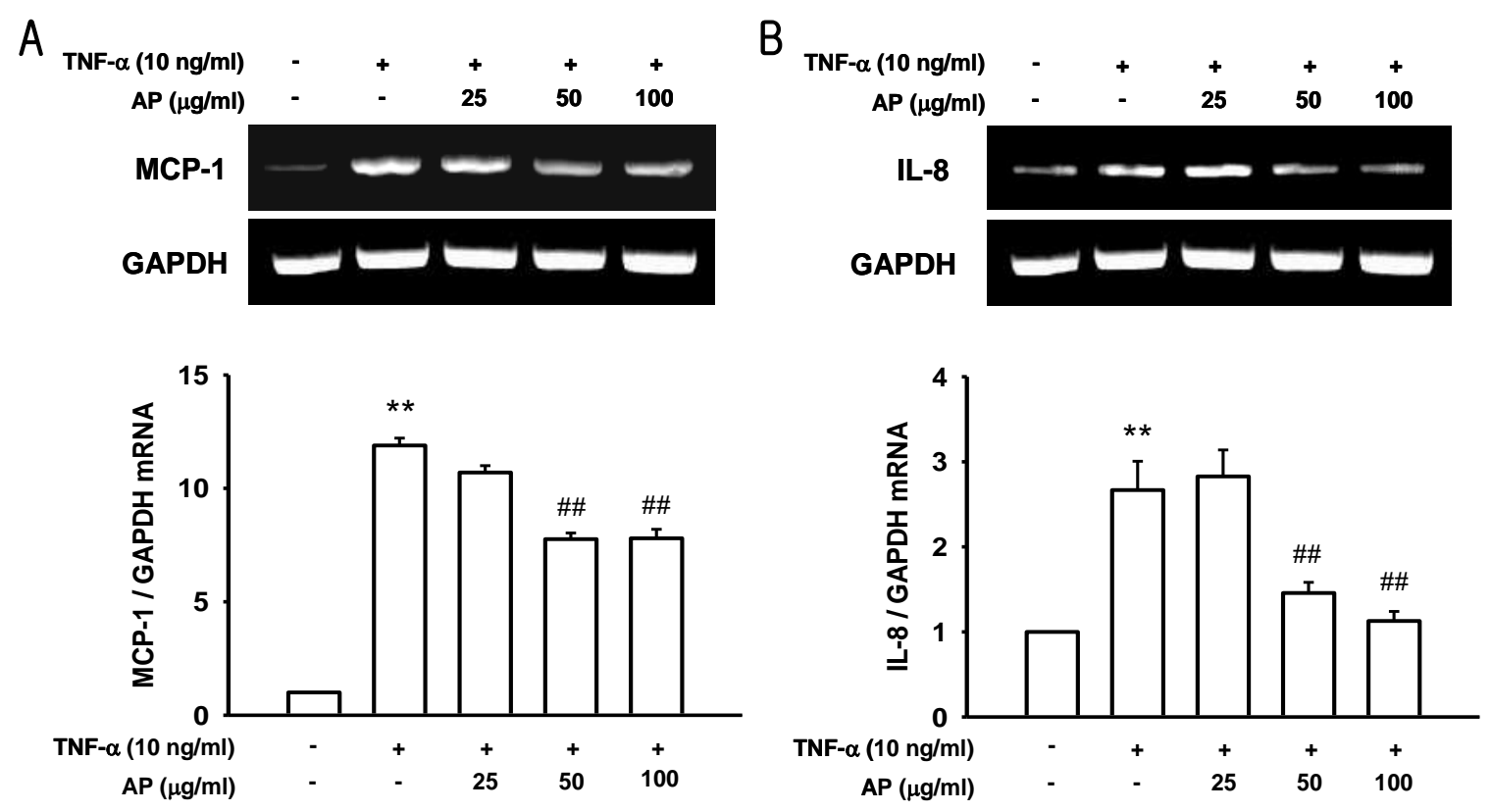

It has been also shown that activation of the transcription factor NF- $\kappa \mathrm{B}$ by $\mathrm{TNF}-\alpha$ is required for the transcriptional activation of endothelial cell adhesion molecules [29]. Nuclear factor $\kappa \mathrm{B}(\mathrm{NF}-\kappa \mathrm{B})$ has been implicated in the transcriptional activation of numerous genes, including those relevant to atherogenesis and inflammatory responses [30,31]. NF- $\mathrm{B}$ is found in an inactive form in the

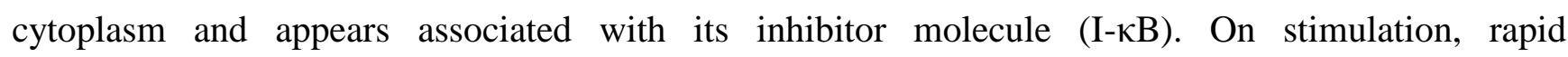
phosphorylation and degradation of $\mathrm{I} \kappa \mathrm{B} \alpha$ allows $\mathrm{NF}-\kappa \mathrm{B}$ to translocate into the nucleus and regulate transcription of the target genes. In cultured human and bovine vascular endothelial cells, p50/p65 heterodimers of NF- $\mathrm{\kappa B}$ appear to play a major role in cytokine-dependent transcription of E-selectin, ICAM-1, and VCAM-1 genes [32]. Furthermore, activation of NF- $\kappa B$ occurs in the vascular endothelium covering atherosclerotic lesions in humans [33]. To study the effect of AP on NF- $\mathrm{B}$ 
activation in TNF- $\alpha$-induced HUVEC, electrophoretic mobility shift assay (EMSA) was performed. As

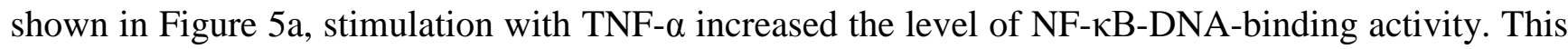
finding was caused by significant retardation in the mobility of the labeled oligonucleotide. In contrast,

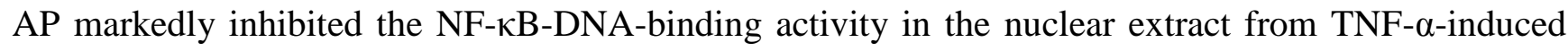
HUVECs. These results therefore, showed that AP inhibits the TNF- $\alpha$-induced NF- $\kappa B$ activation. Using western blot analysis, NF- $\kappa \mathrm{B}$ p65 protein was expressed abundantly in cytoplasm but less in the nucleus of unstimulated cells. However, translocation of NF- $\kappa \mathrm{B}$ p65 from the cytoplasm to the nucleus was significantly increased in TNF- $\alpha$-stimulated cells. TNF- $\alpha$-dependent translocation of NF- $\mathrm{B}$ p65 to the nucleus was markedly suppressed by pretreatment with AP. In contrast, NF- $\kappa$ B p65 protein in the cytosolic extract significantly increased following treatment with AP. Thus, AP inhibited the TNF- $\alpha$-induced increase of NF- $\kappa \mathrm{B}$ p65 expression levels. Pretreatment with AP inhibited I $\mathrm{BB} \alpha$ degradation in a dose dependent manner. Upon induction with TNF- $\alpha$, the intensity of I $\mathrm{B} \alpha$ was significantly reduced. In contrast, pretreatment of cells with AP significantly inhibited the degradation of I $\mathrm{B} \alpha$ in TNF- $\alpha$-induced HUVECs (Figure 5b). This was further confirmed by fluorescence microscopy showing that while cells are in a quiescent state, NF- $\kappa \mathrm{B}$ p65 protein was mainly located in cytoplasm and only a few cells showed a strongly positive nuclear stain, whereas TNF- $\alpha$ profoundly increased the number of nuclei for the p65 NF-kB. However, AP-treated cells represented the diminished staining level of nuclear p65 in a dose dependent manner (Figure 6).

Figure 5. Effect of AP on TNF- $\alpha$-induced NF- $\kappa B$ activation in HUVECs. Cells were preincubated with AP and treated with $10 \mathrm{ng} / \mathrm{mL}$ of TNF- $\alpha$. (a) Nuclear protein extracts were prepared, and electrophoretic mobility shift assay (EMSA) was performed using the biotin-labeled double-stranded oligonucleotide containing consensus NF- $\kappa$ B binding sequences, as described in Materials and Methods; (b) Effect of AP on TNF- $\alpha$-induced $\mathrm{NF}-\kappa \mathrm{B}$ p65 translocation into nucleus and $\mathrm{I} \kappa \mathrm{B} \alpha$ degradation in HUVEC. Each electrophoretogram is representative of the results from three independent experiments.

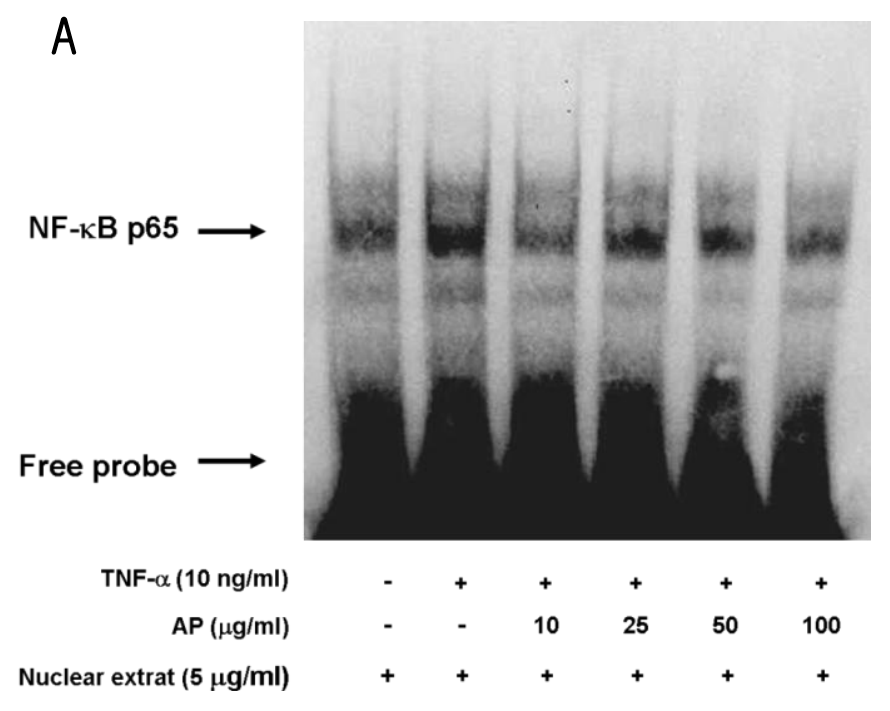

B $\begin{array}{rrrrrrr}\mathrm{TNF}-\alpha(10 \mathrm{ng} / \mathrm{mL}) & - & + & + & + & + & + \\ \mathrm{AP}(\mu \mathrm{g} / \mathrm{ml}) & - & - & 10 & 25 & 50 & 100\end{array}$

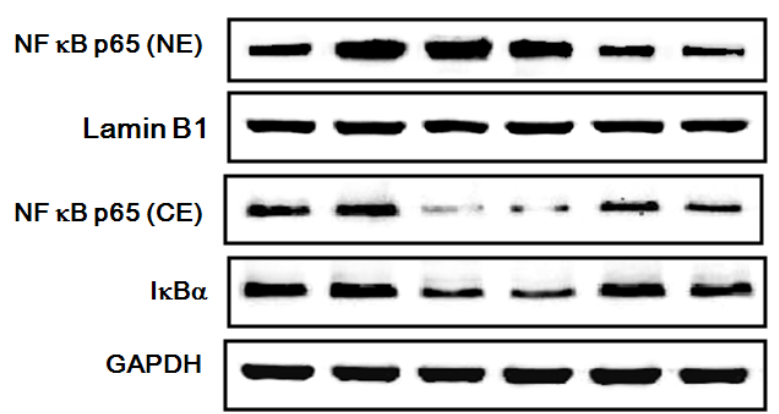


Figure 6. Effect of AP on TNF- $\alpha$-induced NF- $\kappa \mathrm{B}$ nuclear translocation. Subcellular localization of the p65 NF- $\kappa \mathrm{B}$ subunit was assayed with the cell immunofluorescence technique. HUVEC were stained with an antibody versus NF- $\mathrm{B}$ (FITC; green staining), and nuclei were counterstained with DAPI (blue staining). Each electrophoretogram is representative of the results from three individual experiments.

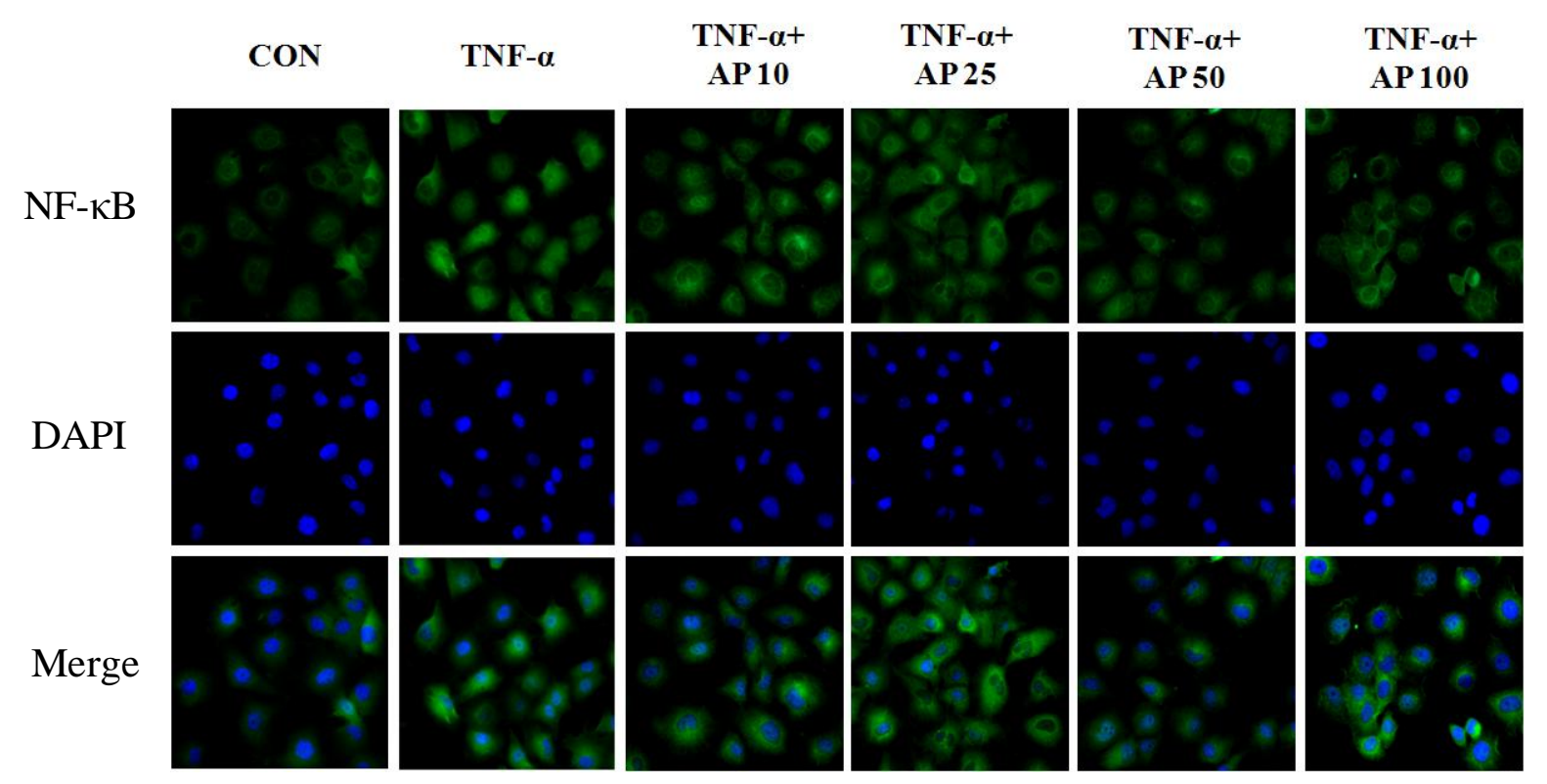

Emerging evidence suggests that TNF- $\alpha$ signaling cascade may cause oxidative stress due to the production of reactive oxygen species, which in turn temporally regulate NF- $\kappa \mathrm{B}$ activity by I $\kappa \mathrm{B}$ kinase with subsequent degradation of $\mathrm{I} \kappa \mathrm{B} \alpha$ [34,35]. Also, a number of antioxidants and free radical quenchers have also been shown to block the NF- $\mathrm{B}$ activation. Reactive oxygen species (ROS) may up-regulate pro-inflammatory gene expression by activating $\mathrm{NF}-\kappa \mathrm{B}$, a process that is itself sensitive to the cellular redox state [36]. Therefore, there has been increasing interest in developing the potential therapeutic value of ROS-antioxidants as inhibitors of NF- $\mathrm{BB}$ from various plants [37]. To examine the protective effect of AP on TNF- $\alpha$-induced intracellular ROS production in HUVECs, we measured DCF-sensitive cellular ROS. This data showed that the intracellular ROS production was significantly increased by stimulation of TNF- $\alpha$. Pretreatment with AP dose-dependently suppressed the TNF- $\alpha$-induced ROS production in HUVECs (Figure 7). These result suggested that antioxidative activity of AP could contribute in part to its inhibitory effects. Several studies have reported that the oxidative stress might contribute to NF- $\mathrm{BB}$-dependent inflammatory responses. Recent studies reported that antioxidant NAC suppresses vascular NF- $\mathrm{BB}$ activation, and this inhibition reduces the pathological thickening of the arterial wall [38]. NF- $\kappa \mathrm{B}$ has been shown to be ROS-sensitive. Therefore, we suggest that the antioxidant property of AP was able to inhibit the TNF- $\alpha$-induced activation of NF- $\mathrm{\kappa B}$.

Recently, our published data suggested that $P$. oleracea ameliorates both vascular inflammation and diabetic nephropathy in $\mathrm{db} / \mathrm{db}$ mice [39]. The major bioactive components of Portulaca oleracea are flavonoids, coumarins, monoterpene glycoside and alkaloids. Furthermore, P. oleracea is a rich source of omega-3 fatty acids, gallotannins, kaempferol, quercetin, apigenin, and glutathione [40,41]. However, the mechanism of action and its compounds have not been clarified [42]. Recently, it has 
been reported that betacyanins from Portulaca oleracea, anthocyanins, ameliorate cognition deficits and attenuate oxidative damage in the brains of senescent mice [43]. Generally, polysaccharides and flavones are the usual anti-diabetic compounds in herbs $[44,45]$. We speculate that various polysaccharides or flavones could participate in the inhibitory effect of vascular inflammation. Thus, further work on isolation and purification of each compound from AP will be done to identify the hypoglycemic effective compounds.

Figure 7. Effect of AP on TNF- $\alpha$-induced ROS production. HUVECs were pretreated with AP $(10-100 \mu \mathrm{g} / \mathrm{mL})$ or NAC $(50 \mu \mathrm{M})$ for $30 \mathrm{~min}$ and then stimulated with/without TNF- $\alpha$ $(10 \mathrm{ng} / \mathrm{mL})$ for $1 \mathrm{~h}$. The fluorescence intensity of cells was measured using a fluorescence microplate. Values are expressed as a mean percentage of the fluorescence intensity \pm S.E. of five individual experiments. $* * p<0.01$ vs. control, ${ }^{\#} p<0.05$, ${ }^{\# \#} p<0.01 v s$. TNF- $\alpha$ alone.

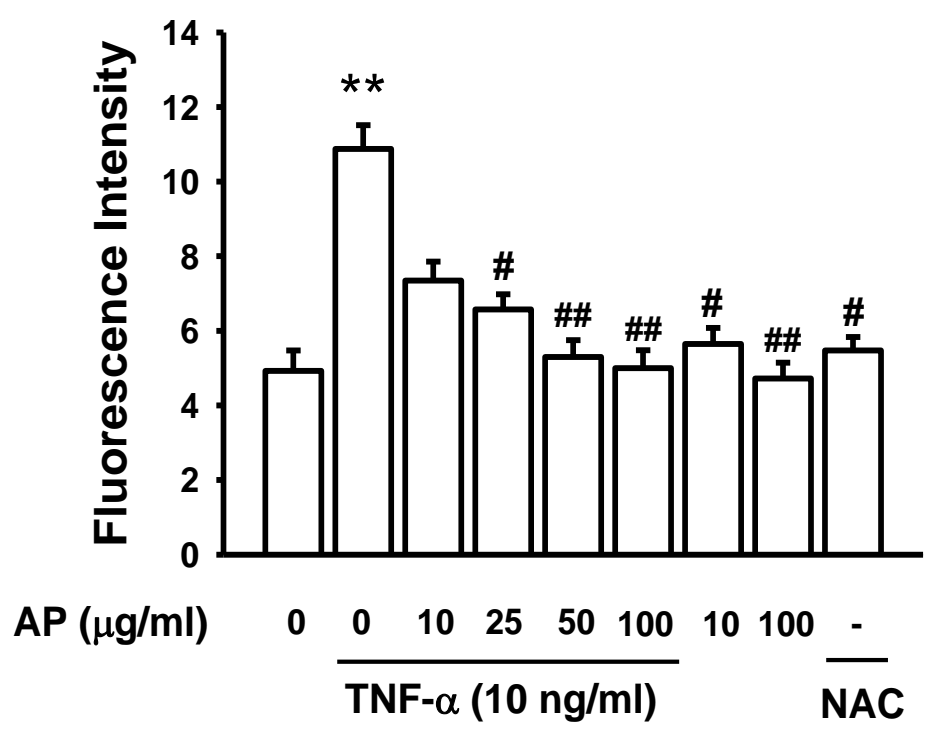

\section{Experimental Section}

\subsection{Extraction of Portulaca oleracea}

The Portulaca oleracea was purchased from the Herbal Medicine Co-operative Association in Jeonbuk Province, Korea. Herbarium voucher specimen (No. HBE121) was deposited in the herbarium of the Professional Graduate School of Oriental Medicine, Wonkwang University, Iksan, Jeonbuk, South Korea. Dried aerial parts of P. oleracea (400 g) were extracted with $5.5 \mathrm{~L}$ of boiled distilled water at $100{ }^{\circ} \mathrm{C}$ for $2 \mathrm{~h}$. The aqueous extract was centrifuged at $1000 \mathrm{~g}$ for $20 \mathrm{~min}$ at $4{ }^{\circ} \mathrm{C}$ and the supernatant was filtered with a Whatman No.3 filter paper, and then concentrated using a rotary evaporator. The supernatant extract was lyophilized to produce a powder, which was then kept at $4{ }^{\circ} \mathrm{C}$ until use in the experiments. The yield of the water extract of P. oleracea was approximately $22.8 \%$ of plant powder. 


\subsection{Cell Culture}

Primary cultured HUVEC and endothelial cell growth medium (EGM-2) containing 2.5\% fetal bovine serum (FBS) and growth supplements were purchased from Cambrex (East Rutherford, NJ). HUVEC which were used between passages three and eight were maintained in EGM-2 in a humidified chamber containing $5 \% \mathrm{CO}_{2}$ at $37^{\circ} \mathrm{C}$.

\subsection{Determination of Cell Based ELISA}

ELISA was used to determine the level of ICAM-1, VCAM-1, and E-selectin expression on the cell surface, as previously described with minor modifications [46]. Briefly, HUVEC were fixed by $1 \%$ paraformaldehyde and exposed to mouse anti-human ICAM-1, VCAM-1, or E-selectin antibodies at 1:1000 dilution in phosphate-buffered saline (PBS) containing 1\% bovine serum albumin (BSA) for $2 \mathrm{~h}$ at room temperature. The cells were washed and incubated with a horseradish peroxidase (HRP)-conjugated secondary antibody. The expression of VCAM-1, ICAM-1, or E-selectin was quantified by adding a peroxidase substrate solution ( $40 \mathrm{mg} o$-phenylenediamine and $10 \mu \mathrm{L} 30 \% \mathrm{H}_{2} \mathrm{O}_{2}$ in $100 \mathrm{~mL} 0.05 \mathrm{M}$ citrate-phosphate buffer). After incubation for $30 \mathrm{~min}$ at $37{ }^{\circ} \mathrm{C}$, the reaction was stopped by addition of $5 \mathrm{~N} \mathrm{H}_{2} \mathrm{SO}_{4}$, and the absorbance of each well was measured at $490 \mathrm{~nm}$ by a Multiskan microplate reader (Thermo LabSystems Inc., Franklin, MA).

\subsection{Monocyte-Endothelial Cell Adhesion Assay}

The cell adhesion assay was modified as described [47]. Briefly, regularly passaged HL-60 cells were labeled with $10 \mu \mathrm{g} / \mathrm{mL}$ 2',7'-bis-(carboxyethyl)-5,6-carboxyfluorescein acetoxymethyl ester (BCECF/AM, Sigma Chemical Co., St. Louis, MO) at $10 \mu \mathrm{M}$ final concentration in RPMI-1640 medium containing $10 \% \mathrm{FBS}$ at $37{ }^{\circ} \mathrm{C}$ for $30 \mathrm{~min}$. The labeled cells were harvested by centrifugation and washed three times with PBS before suspension in the medium, and added to HUVEC in six-well culture plates at $4 \times 10^{5}$ cells $/ \mathrm{mL}$. The co-incubation was done at $37{ }^{\circ} \mathrm{C}$ for $1 \mathrm{~h}$ and nonadhering HL-60 cells (American Type Culture Collection, Manassas, VA) were removed by stringent washing two times with PBS. HL-60 cells bound to HUVEC were measured by fluorescence microscopy (Leica DMIRB, Leica, Germany) and were lysed with $50 \mathrm{mM}$ Tris- $\mathrm{HCl}, \mathrm{pH} 8.0$, containing $0.1 \%$ sodium dodecyl sulfate (SDS). The fluorescent intensity was measured using a spectrofluorometer (F-2500, Hitachi, Tokyo, Japan) at an excitation and emission wavelength of $485 \mathrm{~nm}$ and $535 \mathrm{~nm}$, respectively. The adhesion data are represented in terms of the percentage change compared with the control values.

\subsection{Preparation of Cytoplasmic and Nuclear Extracts}

The cells were rapidly harvested by sedimentation and nuclear and cytoplasmic extracts were prepared on ice as previously described by the method of Mackman et al. [19]. Cells were harvested and washed with $1 \mathrm{~mL}$ buffer A (10 mM HEPES, pH 7.9, $\left.1.5 \mathrm{mM} \mathrm{MgCl}_{2}, 19 \mathrm{mM} \mathrm{KCl}\right)$ for $5 \mathrm{~min}$ at $600 \mathrm{~g}$. The cells were then resuspended in buffer A and $0.1 \% \mathrm{NP} 40$, left for $10 \mathrm{~min}$ on ice to lyse the cells and then centrifuged at $600 \mathrm{~g}$ for $3 \mathrm{~min}$. The supernatant was saved as cytosolic extract. The nuclear pellet was then washed in $1 \mathrm{~mL}$ buffer A at $4200 \mathrm{~g}$ for $3 \mathrm{~min}$, resuspended in $30 \mu \mathrm{L}$ buffer C (20 mM HEPES, pH 7.9, 25\% glycerol, $0.42 \mathrm{M} \mathrm{NaCl}, 1.5 \mathrm{mM} \mathrm{MgCl} 2,0.2 \mathrm{mM}$ EDTA), 
rotated for $30 \mathrm{~min}$ at $4{ }^{\circ} \mathrm{C}$, then centrifuged at $14,300 \mathrm{~g}$ for $20 \mathrm{~min}$. The supernatant was used as nucleus extract.

\subsection{Protein Extraction and Western Blot Analysis}

Cell homogenates (40 $\mu \mathrm{g}$ of protein) were separated on $10 \%$ SDS-polyacrylamide gel electrophoresis and transferred to nitrocellulose paper. Blots were then washed with $\mathrm{H}_{2} \mathrm{O}$, blocked with $5 \%$ skimmed milk powder in Tris-Buffered Saline Tween-20 (TBST) (10 mM Tris-HCl, pH 7.6, $150 \mathrm{mM} \mathrm{NaCl}, 0.05 \%$ Tween-20) for $1 \mathrm{~h}$, and incubated with the appropriate primary antibody at dilutions recommended by the supplier. Then the membrane was washed and primary antibodies were detected with goat anti-rabbit-IgG or rabbit anti-mouse-IgG conjugated to horseradish peroxidase, and the bands were visualized with enhanced chemiluminescence (Amersham Bioscience, Buckinghamshire, UK). Protein expression levels were determined by analyzing the signals captured on the nitrocellulose membranes using the ChemiDoc image analyzer (Bio-Rad Laboratories, Hercules, CA).

\subsection{Electrophoretic Mobility Shift Assay}

Electrophoretic mobility shift assay (EMSA) for NF- $\mathrm{B}$ was performed using TM a lightshiftchemiluminescent EMSA kit (Pierce, Rockford, IL, USA) by following the manufacturer's protocol. To start with, DNA was biotin labeled using the Biotin 3' endlabeling kit (Pierce, Rockford, IL, USA). Briefly, in a $50 \mu \mathrm{L}$ reaction buffer, 5 pmol of double-stranded NF- $\kappa B$ oligonucleotide 5'-GAT CTC AGA GGG GAC TTT CGA GAG A-3'; 3'-CTA GAG TCT CCC CTG AAA GGC TCT CT-5' was incubated in a microcentrifuge tube with $10 \mu \mathrm{L}$ of 5.terminal deoxynucleotidyl transferase (TdT) buffer, $5 \mu \mathrm{L}$ of $5 \mathrm{M}$ biotin-N4-CTP, $10 \mathrm{U}$ of diluted TdT, and $25 \mu \mathrm{L}$ of ultrapure water and incubated at $37{ }^{\circ} \mathrm{C}$ for $30 \mathrm{~min}$. The reaction was stopped with $2.5 \mu \mathrm{L}$ of $0.2 \mathrm{M}$ EDTA. To extract labeled DNA, $50 \mu \mathrm{L}$ of chloroform: isoamyl alcohol (24:1) was added to each tube and centrifuged briefly at 13,000 rpm. The top aqueous phase containing the labeled DNA was removed and saved for binding reactions. Each binding reaction contained $1 \times$ binding buffer $(100 \mathrm{mM}$ Tris, $500 \mathrm{mM} \mathrm{KCl}$, $10 \mathrm{mM}$ dithiothreitol, $\mathrm{pH} 7.5$ ), $2.5 \%$ glycerol, $5 \mathrm{mM} \mathrm{MgCl}_{2}, 50 \mathrm{ng} / \mu \mathrm{L}$ poly (dI-dC), $0.05 \% \mathrm{NP}-40$, $5 \mu \mathrm{g}$ of nuclear extract and 20-50 fm of biotin-endlabeled target DNA. The content was incubated at room temperature for $20 \mathrm{~min}$. To this reaction mixture, $5 \mu \mathrm{L}$ of $5 \times$ loading buffer was added, subjected to gel electrophoresis on a native polyacrylamide gel, and transferred to a nylon membrane. When the transfer was complete, DNA was crosslinked to the membrane at $120 \mathrm{~mJ} / \mathrm{cm}^{2}$ using a UV crosslinker equipped with $254 \mathrm{~nm}$ bulbs. The biotin-endlabeled DNA was detected using streptavidin-HRP conjugate and a chemiluminescent substrate. The membrane was exposed to using digitalized scientific software program Quantity One ${ }^{\circledR}$ (Silk Scientific Corporation, Orem, UT, USA).

\subsection{RNA Isolation and RT-PCR Analysis}

Total RNA was isolated from cultured endothelial cells using a commercially available kit (RNeasy Mini Kit; Qiagen, Valencia, CA, USA). Briefly, cells were washed with PBS, and then RLT buffer (containing $10 \% \quad \beta$-mercaptoethanol) was used. Supernatants were transferred into RNase-free microcentrifuge tubes, $70 \%$ ethanol was added, and the mixture was applied to a Total RNA Mini 
column, centrifuged, and the flow-through discarded. Bound RNA in the column was eluted by RNase-free $\mathrm{ddH}_{2} \mathrm{O}$, and RNA was stored at $-80{ }^{\circ} \mathrm{C}$. The $\mathrm{OD}_{260}$ and $\mathrm{OD}_{260 / 280}$ values were measured with a spectrophotometer to determine the RNA concentrations. Briefly, in the first step, cDNA was prepared from $500 \mathrm{ng}$ RNA by reverse transcription in a final volume of $20 \mu \mathrm{L}$ in an Opticon MJ Research instrument. The samples were incubated at $37{ }^{\circ} \mathrm{C}$ for $60 \mathrm{~min}$ and $94{ }^{\circ} \mathrm{C}$ for $5 \mathrm{~min}$. cDNA was stored at $-20^{\circ} \mathrm{C}$. cDNA samples were analyzed for the specific cDNA of VCAM-1, MCP-1, IL-8, and GAPDH by PCR amplification using specific primers (Table 1). Template cDNA and $50 \mathrm{nM}$ primers were placed in PCR Pre-mix according to the manufacturer's specification (Bioneer, Korea). The amplification profile was as follows: an initial cycling at $94{ }^{\circ} \mathrm{C}$ for $15 \mathrm{~min}$ followed by 45 cycles of $94{ }^{\circ} \mathrm{C}, 20 \mathrm{~s} ; 60{ }^{\circ} \mathrm{C}, 20 \mathrm{~s} ; 72{ }^{\circ} \mathrm{C}, 30 \mathrm{~s}$ and a final extension of $72{ }^{\circ} \mathrm{C}$ for $5 \mathrm{~min}$. The PCR products were subjected to $1.2 \%$ agarose gel electrophoresis. Quantitative data normalized to GAPDH were obtained from a densitometer and analyzed with the included Quantity One software (Silk Scientific Corporation, Orem, UT, USA).

Table 1. Oligonucleotide primer used for RT-PCR.

\begin{tabular}{c|l}
\hline \hline Primer & \multicolumn{1}{c}{ Sequence } \\
\hline VCAM-1 & $\begin{array}{l}\text { sense : CAAATCCTTGATACTGCTCATC } \\
\text { anti-sense : TTGACTTCTTGCTCACAGC }\end{array}$ \\
\hline MCP-1 & $\begin{array}{l}\text { sense : CAGCCAGATGCAATCAATGC } \\
\text { anti-sense : GTGGTCCATGGAATCCTGAA }\end{array}$ \\
\hline IL-8 & $\begin{array}{l}\text { sense : GCATAAAGACATACTCCAAACC } \\
\text { anti-sense : ACTTCTCCACAACCCTCTG }\end{array}$ \\
\hline GAPDH & $\begin{array}{l}\text { sense : GCACCGTCAAGGCTGAGAAC } \\
\text { anti-sense : TGGTGGTGAAGACGCCAGT }\end{array}$ \\
\hline \hline
\end{tabular}

\subsection{Immunofluorescence Microscopy}

HUVECs were seeded on sterile slide coverslips in 6 well plates overnight and pretreated with AP before being stimulated with TNF- $\alpha$. After several washes with PBS, cells were fixed with $4 \%$ paraformaldehyde for $30 \mathrm{~min}$ at room temperature and permeabilized with $0.1 \%$ Triton-100 in PBS for $30 \mathrm{~min}$. The cells were overlaid with protease-free BSA for $10 \mathrm{~min}$, rinsed with PBS and incubated with anti-NF- $\kappa$ B p65 (Santa Cruz Biotechnology, CA, USA) for $1 \mathrm{~h}$ at room temperature. Cells were washed three times with PBS and then incubated with FITC-conjugated goat anti-rabbit $\operatorname{IgG}$ as the secondary antibody (Sigma, St Louis, MO, USA). The slides were incubated at $37{ }^{\circ} \mathrm{C}$ for $45 \mathrm{~min}$, and nuclear staining was performed with DAPI (Molecular Probe, Eugene, OR, USA). Cells were finally washed three times with PBS, coverslips were mounted with Dako Fluorescent mounting medium onto glass slides, and examined under a fluorescence microscope (Axiovision 4, Zeiss, Germany).

\subsection{Intracellular ROS Production Assay}

The fluorescent probe, 5-(and-6)-chloromethyl-2',7'-dichlorodihydro-fluorescein diacetate (CM-H $\mathrm{H}_{2}$ DCF-DA), was used to determine the intracellular generation of ROS by stimulation of TNF- $\alpha$. Briefly, the confluent HUVECs in the 24-well plates were pretreated with AP for 30 min. After 
removing the AP from the wells, the cells were incubated with $20 \mu \mathrm{M}$ DCF-DA for $30 \mathrm{~min}$. The cells were then stimulated with TNF- $\alpha(10 \mathrm{ng} / \mathrm{mL})$, and the fluorescence intensity (relative fluorescence units) was measured at an excitation and emission wavelength of $485 \mathrm{~nm}$ and $530 \mathrm{~nm}$, respectively, using a fluorescence spectrophotometer (F-2500, Hitachi, Tokyo, Japan).

\subsection{Statistical Analysis}

Values were expressed as mean \pm S.E. Statistical analyses were performed using analysis of variance followed by the Student's $t$-test and one-way ANOVA. Differences with a value of $p<0.05$ were considered statistically significant.

\section{Conclusions}

Vascular inflammation induced by cytokine occurs early in the development of atherosclerosis, and leads to endothelial dysfunction. The present study indicated that AP significantly suppressed the following events in cultured vascular endothelial cells; TNF- $\alpha$-induced intracellular ROS formation and the redox-sensitive NF- $\kappa \mathrm{B}$ activation via the suppression I $\mathrm{B}$ degradation and phosphorylation, cell adhesion molecules expression, and the adhesion to monocytes. These results demonstrate that AP has anti-vascular inflammatory activity and AP may be useful in the prevention and treatment of vascular inflammatory diseases. Thus, this data has cast a new light on the actions of Portulaca oleracea and its potential benefits in preventing atherosclerosis.

\section{Acknowledgments}

This research was supported by Basic Science Research Program through the National Research Foundation of Korea (NRF) funded by the Ministry of Education, Science and Technology (MEST) (No. 2010-0029465), and a grant [K10040] to DG Kang funded by Korea Institute of Oriental Medicine.

\section{References}

1. Libby, P.; Sukhova, G.; Lee, R.T.; Galis, Z.S. Cytokines regulate vascular functions related to stability of the atherosclerotic plaque. J. Cardiovasc. Pharmacol. 1995, 2, 9-12.

2. Ross, R. Atherosclerosis: An inflammatory disease. N. Engl. J. Med. 1999, 340, 115-126.

3. Quagliaro, L.; Piconi, L.; Assaloni, R.; da Ros, R.; Maier, A.; Zuodar, G.; Ceriello, A. Intermittent HG enhances ICAM-1, VCAM-1 and E-selectin expression in human umbilical vein endothelial cells in culture: The distinct role of protein kinase $\mathrm{C}$ and mitochondrial superoxide production. Atherosclerosis 2005, 183, 259-267.

4. Minami, T.; Aird, W.C. Endothelial cell gene regulation. Trends Cardiovasc. Med. 2005, 15, 174-184.

5. Madge, L.A.; Pober, J.S. TNF signaling in vascular endothelial cells. Exp. Mol. Pathol. 2001, 70, $317-325$. 
6. Ahmad, M.; Zhang, Y.; Parpharalambus, C.; Alexander, R.W. Role of isoprenylcysteine carboxyl methyltransferase in tumor necrosis factor- $\alpha$ stimulation of expression of vascular cell adhesion molecule-1 in ECs. Arterioscler. Thromb. Vasc. Biol. 2001, 22, 759-764.

7. Ramana, K.V.; Bhatnagar, A.; Srivastava, S.K. Inhibition of aldose reductase attenuates TNF- $\alpha$-induced expression of adhesion molecules in endothelial cells. FASEB J. 2004, 18, 1209-1218.

8. Lockyer, J.M.; Colladay, J.S.; Alprin-Lea, W.L.; Hammond, T.; Buda, A.J. Inhibition of nuclear factor $\kappa \mathrm{B}$-mediated adhesion molecule expression in human endothelial cells. Circ. Res. 1998, 82, 314-320.

9. Lee, Y.J.; Kang, D.G.; Kim, J.S.; Lee, H.S. Lycopus lucidus inhibits high glucose-induced vascular inflammation in human umbilical vein endothelial cells. Vascul. Pharmacol. 2008, 48, $38-46$.

10. Kim, H.J.; Park, K.G.; Yoo, E.K.; Kim, Y.H.; Kim, Y.N.; Kim, H.S.; Kim, H.T.; Park, J.Y.; Lee, K.U.; Jang, W.G.; et al. Effects of PGC- $1 \alpha$ on TNF- $\alpha$-induced MCP-1 and VCAM-1 expression and NF- $\kappa \mathrm{B}$ activation in human aortic smooth muscle and endothelial cells. Antioxid. Redox. Signal. 2007, 9, 301-307.

11. Harrison, D.; Griendling, K.K.; Landmesser, U.; Hornig, B.; Drexler, H. Role of oxidative stress in atherosclerosis. Am. J. Cardiol. 2003, 91, 7A-11A.

12. Chen, C.C.; Chow, M.P.; Huang, W.C.; Lin, Y.C.; Chang, Y.J. Flavonoids inhibit tumor necrosis factor- $\alpha$-induced up-regulation of intercellular adhesion molecule-1 (ICAM-1) in respiratory epithelial cells through activator protein-1 and nuclear factor- $\kappa \mathrm{B}$ : Structure-activity relationships. Mol. Pharmacol. 2004, 66, 683-693.

13. Yoon, J.J.; Lee, Y.J.; Kim, J.S.; Kang, D.G.; Lee, H.S. Protective role of betulinic acid on TNF- $\alpha$-induced cell adhesion molecules in vascular endothelial cells. Biochem. Biophys. Res. Commun. 2010, 391, 96-101.

14. Mohanapriya, S.; Senthilkumar, P.; Sivakumar, S.; Dineshkumar, M.; Subbhuraam, C.V. Effects of copper sulfate and copper nitrate in aquatic medium on the restoration potential and accumulation of copper in stem cuttings of the terrestrial medicinal plant, Portulaca oleracea Linn. Environ. Monit. Assess. 2006, 121, 233-244.

15. Rasheed, A.N.; Afifi, F.U.; Shaedah, M.; Taha, M.O. Investigation of the active constituents of Portulaca oleracea L. (Portulacaceae) growing in Jordan. Pak. J. Pharm. Sci. 2004, 17, 37-45.

16. Zhang, X.J.; Ji, Y.B.; Qu, Z.h.Y.; Xia, J.C.h.; Wang, L. Experimental studies on antibiotic functions of Portulaca oleracea L. in vitro. Chin. J. Microecol. 2002, 14, 277-280.

17. Chan, K.; Islam, M.W.; Kamil, M.; Radhakrishnan, R.; Zakaria, M.N.M.; Habibullah, M.; Attas, A. The analgesic and anti-inflammatory effects of Portulaca oleracea L. subsp. sativa (Haw.) Celak. J. Ethnopharmacol. 2000, 73, 445-451.

18. Parry, O.; Marks, J.A.; Okwuasaba, F. The skeletal muscle relaxant action of Portulaca oleracea: Role of potassium ions. J. Ethnopharmacol. 1993, 40, 187-194.

19. Rasheed, A.N.; Afifi, F.U.; Disi, A.M. Simple evaluation of the wound healing activity of a crude extract of Portulaca oleracea L. (growing in Jordan) in Mus musculus JVI-1. J. Ethnopharmacol. 2003, 88, 131-136. 
20. Awad, N.E. Lipid content and antimicrobial activity of phenolic constituents of cultivated Portulaca oleracea L. Bull. Fac. Pharm. 1994, 32, 137-142.

21. Sakai, N.; Inada, K.; Okamoto, M.; Shizuri, Y.; Fukuyama, Y.; Portuloside, A. a monoterpene glucoside from Portulaca oleracea. Phytochemistry 1996, 42, 1625-1628.

22. Liu, L.; Howe, P.; Zhou, Y.F.; Xu, Z.Q.; Hocart, C.; Zhan, R. Fatty acids and beta-carotene in australian purslane (Portulaca oleracea) varieties. J. Chromatogr. A. 2000, 893, 207-213.

23. Che, W.; Lerner-Marmarosh, N.; Huang, Q.; Osawa, M.; Ohta, S.; Yoshizumi, M. Insulin-like growth factor-1 enhances inflammatory responses in ECs: Role of Gab1 and MEKK3 in TNF- $\alpha$-induced c-Jun and NF- $\kappa \mathrm{B}$ activation and adhesion molecule expression. Circ. Rec. 2002, 90, 1222-1230.

24. Abou-Raya, A.; Abou-Raya, S. Inflammation: A pivotal link between autoimmune diseases and atherosclerosis. Autoimmun. Rev. 2006, 5, 331-337.

25. Sneddon, A.A.; McLeod, E.; Wahle, K.W.; Arthur, J.R. Cytokine-induced monocyte adhesion to endothelial cells involves platelet-activating factor: Suppression by conjugated linoleic acid. Biochim. Biophys. Acta 2006, 1761, 793-801.

26. Lee, D.K.; Nathan, Grantham. R.; Trachte, A.L.; Mannion, J.D.; Wilson, C.L. Activation of the canonical Wnt/beta-catenin pathway enhances monocyte adhesion to endothelial cells. Biochem. Biophys. Res. Commun. 2006, 347, 109-116.

27. Gerszten, R.E.; Garcia-Zepeda, E.A.; Lim, Y.C. MCP-1 and IL-8 trigger firm adhesion of monocytes to vascular endothelium under flow conditions. Nature 1999, 398, 718-723.

28. Yang, Y.Y.; Hu, C.J.; Chang, S.M.; Tai, T.Y.; Leu, S.J. Aspirin inhibits monocyte chemoattractant protein-1 and interleukin-8 expression in TNF- $\alpha$ stimulated human umbilical vein endothelial cells. Atherosclerosis 2004, 174, 207-213.

29. Collins, T.; Read, M.A.; Neish, A.S.; Whitley, M.Z.; Thanos, D.; Maniatis, T. Transcriptional regulation of endothelial cell adhesion molecules: NF- $\mathrm{BB}$ and cytokine inducible enhancers. FASEB J. 1995, 9, 899-909.

30. Murase, T.; Kume, N.; Hase, T.; Shibuya, Y.; Nishizawa, Y.; Tokimitsu, I.; Kita, T. Gallates inhibit cytokine-induced nuclear translocation of NF- $\mathrm{BB}$ and expression of leukocyte adhesion molecules in vascular endothelial cells. Arterioscler. Thromb. Vasc. Biol. 1999, 19, 1412-1420.

31. Kanters, E.; Pasparakis, M.; Gijbels, M.J.; Vergouwe, M.N.; Partouns-Hendriks, I.; Fijneman, R.J.; Clausen, B.E.; Förster, I.; Kockx, M.M.; Rajewsky, K.; et al. Inhibition of $\mathrm{NF}-\kappa \mathrm{B}$ activation in macrophages increases atherosclerosis in LDL receptor-deficient mice. J. Clin. Invest. 2003, 112, 1176-1185.

32. Trivedi, C.M.; Patel, R.C.; Patel, C.V. Homeobox gene HOXA9 inhibits nuclear factor-кB dependent activation of endothelium. Atherosclerosis 2007, 195, e50-e60.

33. Hajra, L.; Evans, A.I.; Chen, M.; Hyduk, S.J.; Collins, T.; Cybulsky, M.I. The NF-кB signal transduction pathway in aortic endothelial cells is primed for activation in regions predisposed to atherosclerotic lesion formation. Proc. Natl. Acad. Sci. USA 2000, 97, 9052-9057.

34. Kumar, S.; Sharma, A.; Madan, B.; Singhal, V.; Ghosh, B. Isoliquiritigenin inhibits IкB kinase activity and ROS generation to block TNF- $\alpha$ induced expression of cell adhesion molecules on human endothelial cells. Biochem. Pharmacol. 2007, 73, 1602-1612. 
35. Bonizzi, G.; Piette, J.; Merville, M.P.; Bours, V. Cell type-specific role for reactive oxygen species in nuclear factor- $\kappa \mathrm{B}$ activation by interleukin-1. Biochem. Pharmacol. 2000, 59, 7-11.

36. Schoonbroodt, S.; Piette, J. Oxidative stress interference with the nuclear factor- $\kappa \mathrm{B}$ activation pathways. Biochem. Pharmacol. 2000, 60, 1075-1083.

37. Calixto, J.B.; Campos, M.M.; Otuki, M.F.; Santos, A.R. Antiinflammatory compounds of plant origin. Part II. Modulation of pro-inflammatory cytokines, chemokines and adhesion molecules. Planta Med. 2004, 70, 93-103.

38. Hayashi, K.; Takahata, H.; Kitagawa, N. N-acetylcysteine inhibited nuclear factor- $\kappa \mathrm{B}$ expression and the intimal hyperplasia in rat carotid arterial injury. Neurol. Res. 2001, 23, 731-738.

39. Lee, A.S.; Lee, Y.J.; Lee, S.M.; Yoon, J.J.; Kim, J.S.; Kang, D.G.; Lee, H.S. Portulaca oleracea ameliorates diabetic vascular inflammation and endothelial dysfunction in $\mathrm{db} / \mathrm{db}$ mice. Evid. Based Complement Alternat Med. 2012, 2012, doi:10.1155/2012/741824.

40. Radhakrishnan, R.; Zakaria, M.N.; Islam, M.W.; Chen, H.B.; Kamil, M.; Chan, K. Neuropharmacological actions of Portulaca oleracea L v. sativa (Hawk). J. Ethnopharmacol. 2001, 76, 171-176.

41. Cai, Y.; Luo, Q.; Sun, M.; Corke, H. Antioxidant activity and phenolic compounds of 112 traditional Chinese medicinal plants associated with anticancer. Life Sci. 2004, 74, 2157-2184.

42. Gao, D.; Li, Q.; Fan, Y. Hypoglycemic effects and mechanisms of Portulaca oleracea L. in alloxan-induced diabetic rats. J. Med. Plants Res. 2010, 4, 1996-2003.

43. Wang, C.Q.; Yang, G.Q. Betacyanins from Portulaca oleracea L. ameliorate cognition deficits and attenuate oxidative damage induced by D-galactose in the brains of senescent mice. Phytomedicine 2010, 17, 527-532.

44. Zhao, R.; Li, Q.; Xiao, B. Effect of Lycium barbarum polysaccharide on the improvement of insulin resistance in NIDDM rats. Yakugaku Zassh. 2006, 125, 981-988.

45. Singab, A.N.; El-Beshbishy, H.A.; Yonekawa, M.; Nomura, T.; Fukai, T. Hypoglycemic effect of Egyptian Morus alba root bark extract: Effect on diabetes and lipid peroxidation of streptozotocin-induced diabetic rats. J. Ethnopharmacol. 2005, 100, 333-338.

46. Manduteanu, I.; Voinea, M.; Antohe, F.; Dragomir, E.; Capraru, M.; Radulescu, L.; Simionescu, M. Effect of enoxaparin on high glucose-induced activation of endothelial cells. Eur. J. Pharmacol. 2003, 477, 269-276.

47. De Clerck, L.S.; Bridts, C.H.; Mertens, A.M.; Moens, M.M.; Stevens, W.J. Use of fluorescent dyes in the determination of adherence of human leucocytes to endothelial cells and the effect of fluorochromes on cellular function. J. Immunol. Methods. 1994, 172, 115-124.

(C) 2012 by the authors; licensee MDPI, Basel, Switzerland. This article is an open access article distributed under the terms and conditions of the Creative Commons Attribution license (http://creativecommons.org/licenses/by/3.0/). 